\title{
Going International: The Experience of Chinese Companies
}

\author{
Qiang Ding \\ Waikato Management School, The University of Waikato \\ Private Bag 3105, Hamilton, New Zealand \\ E-mail:qd8@waikato.ac.nz \\ Michèle E.M. Akoorie \\ Waikato Management School, The University of Waikato \\ Private Bag 3105, Hamilton, New Zealand \\ E-mail:mema@waikato.ac.nz \\ Kathryn Pavlovich \\ Waikato Management School, The University of Waikato \\ Private Bag 3105, Hamilton, New Zealand \\ E-mail: KPAV@waikato.ac.nz
}

\begin{abstract}
To date, China's offshore factories and outward FDI have received little attention in the literature, even if China has been the country with the largest outward FDI of all of the developing nations. The objective of this paper is to provide a contribution to the understanding of Chinese enterprise activity abroad, drawing on the published documents and case analysis. The paper highlights that Chinese firms need to take a learning approach to their internationalization process going international not only means to gain access to new markets abroad, or make better use of the internal production capacity, it still can be an opportunity to learn from the international business environment and make the organization look beyond its daily routines.
\end{abstract}

Keywords: Internationalization, Outward FDI, China

\section{Introduction}

By February 2006, China had replaced Japan as the largest nation holding foreign exchange reserves, reaching USD 853.7 billion (Macartney \& Duncan, 2006). These data, however, just show one side of China's "open door" policy. Since the early stages of the "open door" policy, China's central government has not just focused on encouraging inflow of FDI or exporting "Made-in-China" goods all over the world. It has supported its state-owned enterprises to invest in other countries for diversified motivations (Child \& Rodrigues, 2005).

China is now increasingly integrated into the global economy. According to UNCTAD (2004) data, China has emerged as one of the largest sources of outward direct investment among developing economies. The average annual outward FDI flows from China have grown from USD 0.4 billion in the 1980s to USD 2.3 billion in the 1990s, reaching over USD 41 billion by the end of 2004 (Ministry of Commerce, 2005). Compared with other countries, China has become the fifth largest outward FDI investor in the world.

With rapid economic growth and export expansion, the expectation of growing outward activity could, therefore, be anticipated to proceed along the lines of Dunning's Investment Development Path (Dunning, 1981). The IDP suggests that inward FDI assists in upgrading domestic firm competitiveness, so that in a later stage of the IDP these firms are able to undertake outward FDI in other locations. While the original studies of the IDP suggested that developed country MNEs undertook outward FDI to leverage off their ownership specific assets, more recent studies (Narula, 1996) suggest that developing country MNEs engage in asset seeking FDI, either to acquire natural or intangible assets.

To date, China's offshore factories and outward FDI have received little attention in the literature, even if China has been the country with the largest outward FDI of all of the developing nations. Some studies of China's government-guided outward FDI have been reported by McDermott and Huang (1996); Child and Rodrigues (2005); Zhang and Van Den Bulcke (1996); and Huang (2003). However, the outward direct investment (OFDI) of Chinese 
firms has not been systematically evaluated from a strategic and operational perspective.

The objective of this paper is to provide a contribution to the understanding of Chinese enterprise activity abroad, drawing on the published documents and case analysis. The paper highlights that Chinese firms need to take a learning approach to their internationalization process. The remainder of the paper is organized in the following way. The second section discusses macroeconomic and microeconomic aspects of Chinese outward FDI. The motivations of Chinese firms to "Go Global" are explained in the third section. The fourth section addresses the process of internationalization; that is the entry modes used by Chinese firms. In the fifth section we discuss the advantages and disadvantages of different routes towards internationalization. The sixth section of the paper discusses the problems of Chinese firm internationalization. Solving these problems and improving international competitiveness is the subject of the sixth section. A brief conclusion is then offered.

\section{Macro and Microeconomic Aspects of Chinese Outward FDI}

At the macroeconomic level, the strategy of going overseas via direct investment has long enjoyed official support when directed toward genuine capability enhancement (Wong \& Chan, 2003). The Chinese government, as with others, has recognized the crucial importance of multinational operations in a global era, and has been actively promoting outward FDI. In 1999, the Chinese government launched its 'Go Global' policy, encouraging strong Chinese enterprises to invest more overseas in order to improve their competitiveness and secure an international business presence. This policy signifies the determination of the government to promote outward FDI in the context of huge inflows of foreign exchange. One of the most important ways it sponsors overseas expansion is through the provision of low interest loans to fund the purchase of foreign companies from sources it controls such as China's state banks (The Economist, 2005).

At the firm level, China's enterprises have a strong interest in implementing their internationalization strategies by the way of overseas investment. Several scholars have traced the way that the internationalization of Chinese enterprises has evolved through a number of stages (e.g., Cai, 1999; Tseng, 1994; Warner, $\mathrm{Ng} \& \mathrm{Xu}, 2004$ ). The earlier stages up to the 1990s were largely experimental and subject to strong state regulation. The 1990s witnessed a significantly greater expansion of overseas Chinese affiliates, but problems often arose from a lack of strategic focus, from the limited scale and fragmentation of many projects, and from inexperience in coordinating overseas operations (Warner, $\mathrm{Ng} \mathrm{\&} \mathrm{Xu}$, 2004; Zhang \& Van Den Bulcke, 1996). Many of these overseas affiliates were unprofitable (Cai, 1999; Quan, 2001). It is only recently that a number of leading Chinese firms have begun to internationalize with a view to becoming global players in international markets. They have taken a more focused and longer-term strategic view and appear to be developing the capacity to organize overseas operations systematically.

Some Chinese brands have achieved considerable success in the global market. A few domestically strong companies have expanded successfully into overseas markets (The Economist, 1999; Zhang, 2000; Gilmore \& Dumont, 2003) including Haier (home appliances), Konka (color television), TCL (multi-electronics), Jianlibao (beverage), Tsingtao (beer), Galanz (microwave) and others. The Haier Group occupied almost half of the U.S. small refrigerator's market in 2002. Galanz, which produces one third of microwave ovens in the world, captured a 40 percent of European market in 2002 under its own brand name (Zeng \& Williamson, 2003).

\section{Motivations for Chinese Firms to "Go Global"}

There are a number of reasons to explain why Chinese firms are "going global". Some of the reasons are similar to those driving Western MNCs to invest overseas, but for Chinese firms, there are still some unique features (Child \& Rodrigues, 2005). The first motivation is to secure markets abroad. To gain access to industrialized country markets, some garment manufacturing companies from China have invested in LDCs (Less Developed Countries) such as Mauritius that enjoy preferential trade privileges in the US and European markets. The second motivation is to gain access to superior technology, management knowledge and brands. The most recent case is that of the Chinese firm Lenovo which acquired a stake in IBM PC business. IBM's PC business had been relatively unprofitable for many years; but for Lenovo, it was a good opportunity to leverage off the IBM brand. The third motivation is to secure long-term supplies of natural resources (such as crude oil, natural gas, iron ore and other minerals) to meet domestic industrial demands and national security. China will be a net importing country in natural resources and raw materials until 2020 (Lee, 1996). This explains why some of the state-owned enterprises, like the Sinopec and PetroChina have invested in oil, gas and mining activities in other developing countries, including Indonesia, Kazakhstan, Sudan and Yemen. While cost reduction is one of the major motives for MNCs from developed countries, firms from the developing countries are less driven by cost considerations (because those developing countries are rich in cheap labor resources).

Lastly, the impact of tough domestic competitive conditions in China means that to enhance their competitiveness Chinese companies need to look for opportunities abroad. The restriction facing China is that domestic competition is becoming more intense and reliance on exports is rising. The intensity of competition can be shown from the fall in profitability. The rate of profit return for industrial firms reduced from about 22 percent in 1986 to 5.2 percent for all industrial enterprises in 2002 (China's Statistical Yearbook, 2003). 


\section{The Process of Internationalization: Entry Mode Strategy}

Internationalization is defined as 'the crossing of national boundaries in the process of growth' (Buckley \& Ghauri, 1999, p.ix). According to this definition, China is currently the most active internationalizing economy among the developing countries. By the end of 2005, Mainland Chinese firms had established 7870 branch companies in over 160 countries or regions (Chung, 2004). Chinese companies have adopted the following different entry models for going global. Exporting is the most popular means for Chinese companies, especially at the beginning of 1980s when China adopted the 'open door' policy. This model does not involve any direct investment or active organizational presence abroad. China is now the world third largest exporter after Germany and the United States (Finfacts, 2005; Williams, 2005). Original Equipment Manufacture (OEM) combines the cost advantage of a Chinese enterprise with the brand advantage of a foreign firm for achieving economies of scale and manufacturing excellence. Galanz is a good example of this OEM strategy. Galanz - based in Guangdong Province - is the world's largest manufacturer of microwave ovens. It also dominates two thirds of the Chinese domestic market. Galanz chose to use the OEM route to produce microwaves for many different international brands. It has grown into a dominant manufacturer and its bargaining power over foreign buyers has increased accordingly.

Joint Ventures are favored by China's authorities and enterprises as the fastest way to gain access to R\&D and manufacturing facilities, to transfer technology and expertise to Chinese firms (Peng, 2000; Child \& Yan, 2001; Guthrie, 2005). One example is TCL. TCL is the second-largest electronics company in China. The company manufactures TVs, handsets, PCs, and recently moved into white goods. TCL set up a joint venture with Alcatel and Toshiba to produce handsets and white goods products. The downside of a joint venture is that it is sometimes difficult to manage the joint venture because cooperative partners may have differences in business cultures and management processes. Mergers and Acquisitions by Chinese firms have grown rapidly in recent years. They were valued at USD 2.85 billion in 2003 and USD 7 billion in 2004 (Business Week, 2004). Major acquisitions have been undertaken by large state corporations with the intention of securing raw material supplies (McGregor, 2005).

In 2004/05, a state-owned company SAIC (Shanghai Automotive Industrial Corporation) negotiated an M \& A with UK's automaker MG Rover. SAIC has already had two successful joint ventures in China with Volkswagen and General Motors respectively, but these two MNC partners totally control their brands and the core technology. The motivation for this acquisition attempt was that SAIC wanted to acquire its own technology and brand through an international purchase (The Guardian, 2004). So, if the deal with MG Rover had been successful, this would give SAIC an advantage - it could control MG Rover's brands, design, and technology. Unluckily, the deal was not successful.

Greenfield Establishment of Subsidiaries is a more advanced level of the internationalization process and it involves purchasing overseas assets and establishing subsidiaries within targeted markets. Qingdao Haier is the top Chinese electronics company, specializing in low-cost white goods, air conditioners, microwave ovens, TVs, handsets and PCs. Haier's international expansion strategy is firstly, to enter more difficult, advanced markets such as Europe, USA and Japan markets and then go to the easier, underdeveloped markets such as Indonesia, the Philippines and Malaysia. Haier started to export to Europe and the USA in 1990 and to Japan in 1991. By 2004 Haier's sales had reached USD12 billion including USD 1 billion in exports and USD 1 billion from offshore manufacturing (Business Week, 2004).

\section{Advantages and Disadvantages of Different Entry Modes}

Analysts have identified several primary routes toward internationalization by Chinese firms beyond the level of exports, OEM, joint ventures, M\&A, and greenfield establishment of subsidiaries (Child \& Yan, 2001; Guthrie, 2005). Each route offers certain advantages and risks. Basically, OEM and joint ventures can be served as a preparation for eventual M\&A, and Greenfield Establishment of Subsidiaries. A given firm can consider more than one of these routes at the same time. The OEM/JV route enables a firm to capitalize on low cost production in China and reduce the liability of foreignness. The risk is potential conflicts between cooperative partners, and it is not easy to control a cooperative structure The M\&A route can secure the desired technology and/or brands rapidly with their existing cost advantages. The challenges could be paying more than the asset is worth, the liability of foreignness in managing acquired assets and the acquired assets or brands gradually becoming useless and losing value over time. The greenfield establishment of subsidiaries route means setting up offshore $\mathrm{R} \& \mathrm{D}$, local design, local manufacturing and local sales in worldwide markets. On the positive side, it is easier to implement a localization strategy, which can permit a Chinese firm to hire its own personnel and introduce its own practices. Liability of foreignness can be reduced through training locally selected staff in parent company administrative practices. By being present as a local company in a highly competitive market such as the USA, this expansion route also strengthens the credibility of the company's brand. The risk is that this strategy is a slower route to internationalization. As in Haier's case, it may involve the establishment of production abroad in addition to technical and marketing facilities. It tends to be a high-cost investment route that can impose financial risk and pressure on the company. 


\section{Some Problems of Chinese Internationalization}

Going global is not an easy task and investing overseas is a challenging job. Some overseas Chinese firms have had many problems. Nolan (2001, p.187) has argued that 'the competitive capability of China's large firms after two decades of reform is still painfully weak in relation to the global giants'. Compared with the MNCs from the developed countries, the weaknesses of Chinese firms can include; limited knowledge of overseas markets and limited marketing capability; weakness in R\&D; lack of international brands or trade names; a lack of strategic focus and a lack of experience of coordinating overseas operations (Warner, $\mathrm{Ng} \& \mathrm{Xu}, 2004$ ). Many of these overseas affiliates have lost money (Cai, 1999; Quan, 2001). One example is CITIC in New Zealand. CITIC (China International Trust and Investment Corp.) is a Chinese government-controlled investment company, which set up a joint venture with Fletcher Challenge Forests in September, 1996. However, after six years' operation, the joint venture finally failed. Besides currency fluctuation difficulties and the collapse of log prices in international markets, there were other reasons for the failure such as inadequate channels of communication; lack of trust between the partners and poor team cooperation due to intercultural differences.

\section{Being a Global Player in International Markets - Strategic View}

How can Chinese enterprises solve these problems and improve their competitiveness? At least four strategies can be identified. The first is government support. Government should provide access to the financial, technical, human resource assistance to help these enterprises. With government support, enterprises would find it could be easier to compete with other players. Secondly, Chinese firms need to build up new capabilities through the differentiation and brand advantages. Differentiation means demonstrate differences and strengths when comparing with other products and focusing on a niche market as Haier has done. A brand advantage means through building a recognized brand, customers will be willing to pay a higher price for products even though their products have the same qualities and functions as others. Brand recognition is particularly important in consumer markets, such as those for automobiles, beverages, clothing, consumer electronics, household goods, and mobile phones. Building a recognized brand cannot be achieved overnight; it needs continuous investment.

Thirdly, reducing the liability of foreignness - the management of the international firm needs to overcome the differences in business cultures and managerial styles. After Lenovo's acquisition of the IBM PC business, some people were suspicious about Lenovo's capability to preserve IBM PC brand; one IBM user once commented that 'it feels uncomfortable; international IBM has become a domestic Lenovo' (Financial Times, 2004). In order to reduce the risks and the liability of foreignness, Lenovo appointed a former IBM vice-president as its CEO of the new Lenovo, transferring its head office to New York, and still keeping IBM as the after-sales service supplier outside China. Lenovo recognized that it is important to reduce the foreignness during the process of internationalization. The final strategy is ethical considerations and setting up rapport with the local communities. To be a responsible company, Chinese firms need to recognize that profit-seeking is only one objective when making an investment abroad, Chinese enterprises still need to consider how to make a contribution to local communities and to maintain the balance between making money and being a socially responsible enterprise.

\section{Conclusion}

China has been the largest recipient of inward direct investment flows (UNCTAD, 2004) and there is active government policy interest in inward technology transfer (Yan, 2000). China's success in attracting the inflow of FDI has been well documented, however, less known is the initial development of China's "going out" strategy, which encourages domestic enterprises to participate in international capital market and to directly invest overseas. Although the outward internationalization of Chinese enterprises is recent and small scale, there seems little doubt that major growth will continue in the future.

\section{References}

Buckley, P.J., \& Ghauri, P.N. (1999). The internationalization of the firm (Eds.). London: Thomson Business Press.

Business Week. (2004). China goes shopping. December 20, 30-32.

Cai, K. G. (1999). Outward foreign direct investment: A novel dimension of China's integration into the regional and global economy. China Quarterly, 160, December, 856-880.

Child, J., \& Rodrigues, S.B. (2005). The internationalization of Chinese firms: A case for theoretical extension? Management and Organization Review, 1(3), 381-410.

Child, J. \& Yan, Y. (2001). National and transnational effects in international business: Indications from Sino-foreign joint ventures. Management International Review, 41, 53-75.

Chung, O. (2004). Outward FDI tops US\$33bn. The Standard, October 7. From www.thestandard.com.hk.

Dunning, J. H. (1981). Explaining the international direct investment position of countries: Towards a dynamic or 
developmental approach. Weltwirtschaftliches Archiv, 119, 30-64.

Financial Times. (2004). IBM brand loyalty holds key for Lenovo. December 9, 26.

Finfacts. (2005). China exports surge by $32.7 \%$ in first half of 2005. From www.finfacts.com, July 13.

Gilmore, F. \& Dumont, S. (2003). Brand warriors: China creating sustainable brand capital. London: Profile Books Ltd.

Guthrie, D. (2005). Organizational learning and productivity: State structure and foreign investment in the rise of the Chinese corporation. Management and Organization Review, 1, 165-95.

Huang, Y. (2003). Selling China: Foreign direct investment during the reform era. Cambridge: Cambridge University Press.

Lee, C.H. (1996). China's natural resources and economic development. China's Economic Research, 29, 21-26.

Macartney, J. \& Duncan, G. (2006). Chinese foreign reserves to exceed \$1 trillion, March 29, 2006. From www.timesonline.co.uk.

McDermott, M. \& Huang, C. H. (1996). Industrial state-owned multinationals from China: The embryonic years, 1985 92. Asia Pacific Business Review, 3(1), 1-15.

McGregor, R. (2005). Spending spree leaves Beijing nerves frayed. Financial Times, March 8, 12.

Ministry of Commerce. (2005). China outbound investments statistics report for 2004. Beijing: Ministry of Commerce and State Statistical Bureau.

Narula, R. (1996). Multinational investment and economic structure. London: Routledge.

Nolan, Peter. (1999). Restructuring China's large enterprises in the epoch of explosive globalization: Challenge and response. University of Cambridge, Judge Institute of Management Studies.

Peng, M. W. (2000). Business strategies in transition economies. Thousand Oaks, CA: Sage.

Quan, Y. (2001). Access to the WTO and internationalization strategy of Chinese companies. Enterprise Studies, 8, $12-24$.

The Economist. (1999). China brands: Out of the shadows. 28 August, 58-59.

The Economist. (2005). The dragon tucks in. July 2, 70-2.

The People's Republic of China Statistical Yearbook. (2003). Beijing: China Bureau of Statistics of China.

Tseng, C.S. (1994). The process of internationalization of PRC multinationals. In Schultte, H. (Ed.), The global competitiveness of the Asian firm. Basingstoke, UK: Macmillan.

UNCTAD (United Nations Conference on Trade and Development): World investment report (2004). New York: United Nations.

Warner, M., Ng, S.H. \& Xu, X. (2004). "Late development" experience and the evolution of transnational firms in the People's Republic of China. Asia Pacific Business Review, 10, 324-45.

Williams, F. (2005). China overtakes Japan as third largest exporter. Financial Times, April 15,9.

Wong, J. \& Chan, S. (2003). China's outward direct investment: Expanding worldwide. China: An International Journal, 1(2), 273-301.

Yan, Y. (2000). International joint ventures in China: Ownership, control and performance. Macmillan Press Ltd.

Zeng, M. \& Williamson, P.J. (2003). The hidden dragon. Harvard Business Review, October, 92-9.

Zhang, H.Y. \& Van Den Bulcke, D. (1996). International management strategies of Chinese multinational firms. In Child, J. and Lu, Y (Eds.) Management issues in China: International enterprises (pp. 141-64). London: Routledge.

Zhang, R. (2000). We believe, therefore we see. Financial Times, February 24, 8. 